\title{
PENGEMBANGAN PERANGKAT PEMBELAJARAN BERBASIS PENDIDIKAN KARAKTER UNTUK MATA KULIAH STRATEGI PEMBELAJARAN BAHASA JURUSAN PENDIDIKAN BAHASA JEPANG DI UNIVERSITAS PENDIDIKAN GANESHA SINGARAJA
}

\author{
Ni Nyoman Padmadewi \\ Jurusan Pendidikan Bahasa Jepang Fakultas Bahasa dan Seni \\ Universitas Pendidikan Ganesha, Singaraja
}

email: padmadewi@pedulisesamaphilanthropicwork.org

\begin{abstract}
Abstrak
Penelitian ini bertujuan untuk mengembangkan perangkat pembelajaran yang berbasis Pendidikan Karakter untuk Mata Kuliah Strategi Pembelajaran Bahasa di Jurusan Pendidikan Bahasa Jepang. Rancangan penelitiannya menggunakan rancangan penelitian pengembangan (R\&D) yang direncanakan untuk dilaksanakan dalam dua tahun, dimana tahun pertama adalah untuk mengembangkan perangkat pembelajaran yang berbasis Pendidikan Karakter dan tahun kedua adalah untuk menguji efektivitas penggunaannya dalam implementasi di kelas. Artikel ini menyajikan tentang hasil penelitian yang mengembangkan 3 produk utama yaitu silabus, SAP dan RPP, instrument asesmen serta perangkat tambahan untuk memperkuat implementasi pendidikan karakter. Model pengembangannnya memodifikasi model yang dikembangkan oleh Dick dan Carey yang dianalisis dengan menggunakan metode gabungan baik secara kualitatif maupun secara kuantitatif (mixed method). Ada tiga produk utama dan beberapa produk tambahan yang dihasilkan dalam penelitian ini yang bisa diterapkan di Jurusan Pendidikan Bahasa Jepang.
\end{abstract}

Kata kunci: perangkat pembelajaran, pendidikan karakter, strategi pembelajaran

\begin{abstract}
Abtract
This research aimed at developing a set of character based learning instruction instruments for the Strategy of Language Teaching subject at Japanese Education Department. The design of the research used R\&D design which was planned to be carried out in two years in which the first year is for developing the instruments and the second year was for testing the effectiveness of the instrument implementation in the classroom. This article is intended to describe the results of the research which developed 3 main products such as syllabus, SAP and RPP and assessment instrument and equipped with additional products for strengthening the implementation of character education. The model of its development used the modified model of Dick and Carey which was analyzed using mixed method, qualitative as well as quantitative analysis. There are three main documents and added with several additional documents produced which can be implemented in the Japanese Education Department.
\end{abstract}

Keywords: Instruction instruments, character education 


\section{PENDAHULUAN}

Mata kuliah Strategi

Pembelajaran Bahasa merupakan salah satu mata kuliah pedagogik di Jurusan Pendidikan Bahasa Jepang yang memiliki tujuan untuk membekali mahasiswa agar memiliki kompetensi dalam melaksanakan pembelajaran di dalam kelas. Mata kuliah ini memiliki fungsi strategis karena mata kuliah ini merupakan salah satu mata kuliah inti pembentuk kompetensi pedagogik untuk calon guru.

Padmadewi (2012) melakukan penelitian untuk mengembangkan buku ajar Mata Kuliah Strategi Bahasa untuk Jurusan Pendidikan Bahasa Jepang. Buku ajar ini dikembangkan karena adanya kebutuhan mendesak bahwa dosen Jurusan Pendidikan Bahasa Jepang Undiksha belum memiliki latar belakang pendidikan keguruan. Dari enam orang dosen yang bertugas di Jurusan Pendidikan Bahasa Jepang saat ini tidak ada satupun yang memiliki latar belakang pendidikan bahasa dan hanya memiliki satu orang dosen yang sedang menempuh Pendidikan Bahasa di Jepang dan baru akan menyelesaikan studinya dalam dua tahun. Kenyataan ini kalau dibiarkan akan berdampak pada penurunan kualitas pembelajaran di kelas dan dapat menurunkan kualitas lulusan. Fenomena ini juga mengundang saran alumni agar dosen Jurusan Pendidikan Bahasa Jepang meningkatkan keterampilan mereka mengajar (studi lacak alumni, Sri Adnyani dkk., 2011).

Dengan adanya kenyataan akan kekosongan tenaga dosen yang memiliki latar belakang pendidikan bahasa dan memperhatikan masukan dari alumni, penelitian Padmadewi (2012) diharapkan memberikan pemecahan karena buku ajar yang dihasilkan nanti tidak hanya bermanfaat untuk mahasiswa tetapi juga untuk dosen di Jurusan Pendidikan Bahasa Jepang.

Keberadaan buku ajar saja tentu tidak cukup untuk bisa membekali dosen dan mahasiswa dengan kompetensi pedagogik. Apalagi Fakultas Bahasa dan Seni Universitas Pendidikan Ganesha memiliki kebijakan agar menyisipkan Pendidikan Karakter di setiap mata kuliah mulai tahun 2012 ini. Oleh sebab itu, perlu dikembangkan perangkat pembelajaran yang berwawasan Pendidikan Karakter pada mata kuliah Strategi Pembelajaran Bahasa agar mampu membekali mahasiswa dengan kompetensi melaksanakan pembelajaran yang berkarakter. Oleh sebab itu, penelitian ini bertujuan untuk mengembangkan perangkat pembelajaran mata kuliah Strategi Pembelajaran Bahasa yang berwawasan Pendidikan Karakter sehingga buku ajar yang dihasilkan oleh Padmadewi (2012) akan menjadi panduan lengkap yang sangat dibutuhkan oleh Jurusan Pendidikan Bahasa Jepang Universitas Pendidikan Ganesha Singaraja.

Pentingnya dan keutamaan dari penelitian ini dapat dilihat dari kontribusinya terhadap Fakultas Bahasa dan Seni Undiksha dan pembelajaran Bahasa Jepang di Jurusan Pendidikan Bahasa Jepang, serta memiliki kotribusi untuk memperbaiki kualitas jurusan sehingga menjadi lulusan yang berkualitas untuk membangun bangsa. Temuan/inovasi hasil penelitian yang 
ditargetkan adalah adanya perangkat pembelajaran yang berbasis pendidikan karakter yang menjadi panduan bagaimana Buku Ajar Strategi Pembelajaran Bahasa diajarkan di tiaptiap pertemuan oleh dosen Jurusan Pendidikan Bahasa Jepang dengan lebih mudah. Sebagai Mata kuliah inti pembentuk kompetensi pedagogik, mata kuliah ini menjiwai keterampilan mengajar dosen, sehingga tidak hanya bermanfaat untuk meningkatkan keterampilan mengajar dosen dalam Mata Kuliah Strategi Pembelajaran Bahasa tetapi juga dalam mengajarkan mata kuliah lain. Dengan kata lain, dengan adanya penelitian ini, keterampilan dosen dalam mengajar akan meningkat sehingga kualitas pembelajaran yang dilakukan dosen juga meningkat. Artinya, penguasaan terhadap mata kuliah ini akan melahirkan dosen yang terampil mengajar, yang menguasai strategi pembelajaran inovatif dan berkarakter sehingga dari jiwa-jiwa yang terampil dan berkarakter inilah akan dibentuk pencetak guru yang berkualitas yang akan menentukan masa depan generasi penerus bangsa.

Karena penyisipan pendidikan karakter merupakan hal yang baru dan belum ada panduan dan sosialisasi yang jelas tentang bagaimana kongkretnya hal ini dilakukan dalam setiap mata kuliah, diharapkan pula perangkat pembelajaran ini bisa sebagai ajang pembelajaran bagi dosen dalam melaksanakan kebijakan lembaga dalam upaya meningkatkan kompetensi pedagogik mereka dan kompetensi kepribadiannya. Dengan cara ini, diharapkan penampilan keseharian dosen dalam pelaksanaan pembelajaran di kelas akan meningkat. Dengan demikian, mahasiswa akan lebih termotivasi dan lebih mudah memahami pelajaran yang disampaikan sehingga kualitas hasil belajar bisa ditingkatkan yang tentunya akan mengarah pula pada peningkatan kualitas lulusan.

Penelitian ini juga memberi dampak terhadap kualitas pembelajaran Bahasa Jepang di sekolah-sekolah. Seperti diketahui, Jurusan Pendidikan Bahasa Jepang Universitas Pendidikan Ganesha Singaraja adalah satu-satunya Jurusan Pendidikan Bahasa Jepang di Bali yang lulusannya banyak bekerja di sekolah-sekolah yang menggunakan Bahasa Jepang sebagai muatan lokal maupun pada sekolah-sekolah internasional. Hasil observasi peneliti di sekolah dan juga dikonfirmasi saat berpatner dengan pihak sekolah dalam rangka membimbing mahasiswa Jurusan Pendidikan Bahasa Jepang Undiksha dalam kegiatan praktek mengajar, dapat dinyatakan bahwa praktek pelaksanaan pembelajaran Bahasa Jepang masih perlu ditingkatkan. Penekanan pembelajaran ada pada penguasaan tatabahasa dan banyak menggunakan metode terjemahan. Pembelajaran kurang bersifat 'student centred' dan pembelajaran lebih diarahkan pada penguasaan tata kalimat.

Dalam Pedoman Pelaksanaan Pendidikan Karakter (2011) disebutkan bahwa strategi pelaksanaan pendidikan karakter di satuan pendidikan merupakan satu kesatuan dari program manajemen peningkatan mutu berbasis sekolah yang terimplementasikan dalam pengembangan, pelaksanaan dan evaluasi kurikulum oleh setiap satuan pendidikan. Strategi tersebut diwujudkan 
melalui pembelajaran aktif dengan penilaian berbasis kelas disertai program remidiasi dan pengayaan. Kegiatan pembelajaran dalam kerangka pengembangan karakter peserta didik dapat dilaksanakan dalam pembelajaran yang berbasis kontekstual dan peserta didik dilatih untuk menghubungkan teori dengan situasi nyata dalam kehidupan bermasyarakat. Dalam proses pembelajaran tersebut, siswa diarahkan untuk mampu menjadi pribadi yang cerdas, bertanggung jawab, toleransi, terbuka, memiliki rasa ingin tahu dan bertanggung jawab.

Demi terlaksananya pendidikan karakter secara menyeluruh dan berkelanjutan, perlu dikembangkan dan dimplementasikan dalam kegiatan yang diikuti oleh mahasiswa. Agar terjamin dapat dilaksanakan dengan baik, perlu disiapkan dokumen pendukung yang mengatur pelaksanaan pendidikan karakter secara efisien. Agar pendidikan karakter bisa terlaksana dengan baik maka nilai-nilai pembentuk karakter yang diperkenalkan harus dilakukan dalam kehidupan sehari-hari peserta didik dalam berperilaku nyata. Hal ini dilakukan tidak hanya saat ada di sekolah tetapi tercermin menyatu dalam perilaku mahasiswa baik dalam melalukan kegiatan keseharian di rumah maupun dimasyarakat. Oleh sebab itu itu pelaksanaanya harus terorganisir dengan baik baik di tataran rumah, masyarakat maupun pada tataran sekolah dan pemerintah daerah dan pusat.

Menurut Kemendiknas seperti dinyatakan oleh Agus Wibowo (2012) pengembangan kurikulum pendidikan karakter tidak dimasukkan sebagai pokok bahasan tetapi terintegrasi ke dalam mata pelajaran, pengembangan diri dan budaya sekolah. Oleh sebab itu, guru dan pemangku kebijakan pendidikan di sekolah perlu mengintegrasikan nilai-nilai yang dikembangkan dalam pendidikan karakter ke dalam KTSP, silabus, RPP yang sudah ada.

Sehubungan dengan hal tersebut di atas, penelitian ini bertujuan untuk melanjutkan penelitian Padmadewi (2012) yaitu mengembangkan perangkat pembelajaran mata kuliah Strategi Pembelajaran Bahasa yang berwawasan Pendidikan Karakter untuk Jurusan Pendidikan Bahasa Jepang Universitas Pendidikan Ganesha (Undiksha). Secara khusus penelitian ini bertujuan sebagai berikut.

1) untuk merancang dan membuat silabus pembelajaran Strategi Pembelajaran Bahasa yang berwawasan pendidikan karakter.

2) untuk merancang dan membuat Satuan Acara Perkuliahan (SAP) untuk mata kuliah Strategi Pembelajaran Bahasa yang berwawasan pendidikan karakter.

3) untuk merancang dan membuat instrumen assesmen pembelajaran Strategi Pembelajaran Bahasa yang berwawasan pendidikan karakter.

Diharapkan artikel ini bisa menginspirasi para dosen Jurusan pendidikan bahasa Jepang yang samasama mengajar mata kuliah yang sama atau dosen lain dalam hal pengembangan perangkat pembelajaran yang dibutuhkan dalam melaksanakan pembelajaran bahasa asing di kelas.

Jurnal Pendidikan Indonesia |543 


\section{METODE}

Penelitian ini dilakukan dengan menggunakan rancangan $R \& D$ dengan menggunakan model yang dimodifikasi dari desain Dick\& Carey (1990). Subjek penelitian adalah ahli pembelajaran bahasa asing dan dosen pengampu mata kuliah yang memberikan informasi tentang data yang dibutuhkan untuk pengembangan perangkat pembelajaran mata kuliah Strategi Pembelajaran Bahasa.Sesuai dengan rumusan masalah penelitian ini, maka objek penelitian ini adalah perangkat pembelajaran mata kuliah Strategi Pembelajaran Bahasa yang berbasis pendidikan karakter. Penelitian dilakukan di Jurusan Pendidikan Bahasa Jepang Fakultas bahasa dan Seni Universitas Pendidikan Ganesha Singaraja dan data dikumpulkan dengan menggunakan kuesioner maupun lewat wawancara dan dianalisis secara deskriptif kualitatif maupun kuantitatif.

\section{HASIL DAN PEMBAHASAN}

Pada bagian ini dipaparkan hasil penelitian berupa produk perangkat pembelajaran sesuai dengan tujuan penelitian yang dipaparkan sebelumnya. Berikut ini adalah paparan tentang produk yang dihasikan dari penelitian ini.

\section{Silabus Mata Kuliah Strategi Pembelajaran Bahasa.}

Berdasarkan hasil analisis data yang dilakukan dengan menggunakan beberapa instrumen dan dengan menganalisis dokumen yang digunakan di Jurusan Pendidikan Bahasa Jepang Universitas Pendidikan Ganesha Singaraja, dapat dinyatakan bahwa format silabus yang digunakan di Jurusan Pendidikan Bahasa Jepang mengikuti format yang telah ditetapkan oleh Fakultas Bahasa dan Seni Universitas Pendidikan Ganesha Singaraja yang bisa ditampilkan seperti dalam tabel sebagai berikut.

Tabel 1: Silabus Mata Kuliah Strategi Pembelajaran Bahasa

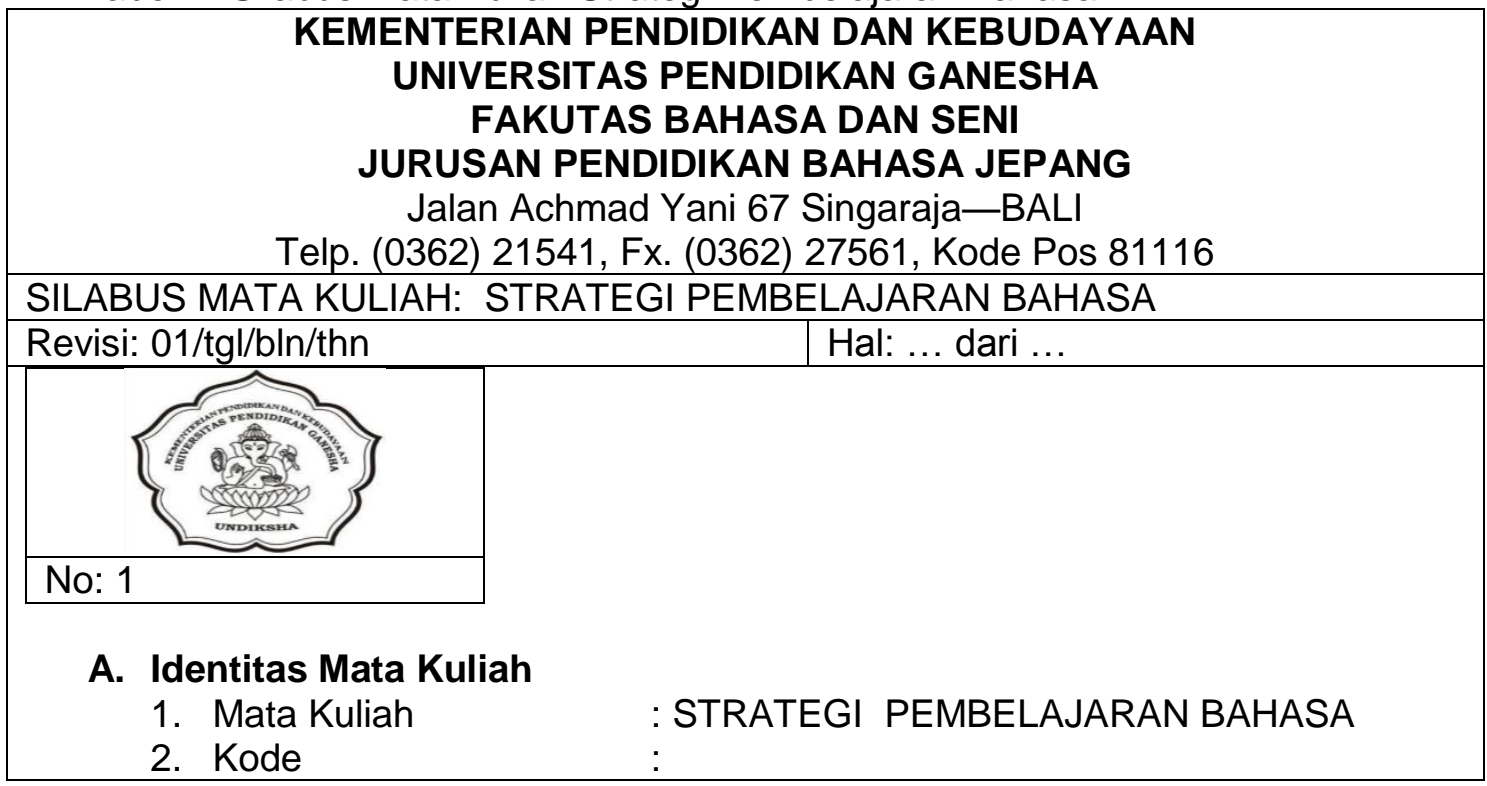



3. Semester
:IV
4. Jurusan/Prog Studi : Pendidikan Bahasa Jepang
5. Jumlah Kredit
: 2 sks
6. Prasyarat
:-

\section{B. Standar Kompetensi}

Mahasiswa memiliki pemahaman dan keterampilan yang mendalam tentang konsep strategi pembelajaran bahasa sesuai dengan filosopi teori bahasa dan teori pembelajaran bahasa serta mampu mengaplikasikan langkah-langkah pembelajaran menjadi pembelajaran kontekstual, inovatif dan menyenangkan.

\section{Kompetensi Dasar}

Mahasiswa memiliki kompetensi tentang berbagai prosedur dan strategi pelaksanaan pembelajaran bahasa yang ada dalam konteks pembelajaran bahasa berdasarkan filosopi teori bahasa dan teori pembelajaran bahasa yang tepat, serta mampu mengaplikasikannya dalam proses pembelajaran.

\section{Tujuan Pembelajaran}

- agar mahasiswa memiliki kompetensi tentang pendekatan, metode dan teknik, dan mampu memaparkan perbedaan ketiga istilah tersebut.

- agar mahasiswa memiliki kemampuan tentang teori bahasa dan teori pembelajaran bahasa dari berbagai metode.

- agar mahasiswa memiliki kompetensi tentang prinsip-pinsip pembelajaran dari berbagai metode pembelajaran bahasa asing.

- agar mahasiswa mampu menjelaskan sintaks pembelajaran untuk tiap-tiap metode.

- agar mahasiswa mampu memaparkan kelemahan dan kekuatan dari tiap-tiap metode.

- agar mahasiswa memiliki kompetensi untuk mempresentasikan/mensimulasikan tiap-tiap metode dalam pembalajaran bahasa Jepang.

\section{E. Deskripsi Mata Kuliah}

Mata kuliah Strategi Pembelajaran Bahasa ini dirancang agar mahasiswa calon guru dibekali dengan kompetensi mengajar dengan menggunakan berbagai metode yang tepat, inovatif dan menyenangkan. Mata kuliah ini mencakup pendekatan, metode dan teknik dalam pembelajaran bahasa, metode translasi gramatika, direct method, metode audiolingual, total physical responce, community language learning, communivative language teaching, pembelajaran cooperative, strategi menggunakan lagu dan permainan, dan strategi 
menyisipkan pendidikan karakter dalam pembelajaran.

\section{F. Metode/Pendekatan}

Pendekatan: Konstruktivism

Metode: Ceramah, diskusi, kerja kelompok/ CLT, presentasi, pembelajaran berbasis projek.

\section{G. Media dan Alat}

LCD sebagai media untuk menampilan power point dan contoh pembelajaran

\section{H. Tugas dan Latihan}

- Membahas tiap-tiap metode dan strategi pembelajaran bahasa

- Diskusi dan kerja kelompok mendiskusikan tentang sintaks pembelajaran untuk tiap-tiap metode; membahas kelemahan dan kekuatan tiap-tiap metode.

- Membuat rancangan pembelajaran yang inovatif.

- Mensimulasikan langkah-langkah pembelajaran untuk tiap-tiap metode.

\section{Evaluasi}

\section{- Project \\ - Presentasi. \\ - Kuis}

\begin{tabular}{|l|l|l|}
\hline \multicolumn{1}{|c|}{ Jenis tagihan } & Bobot & \multicolumn{1}{c|}{ Keterangan } \\
\hline Project dan tagihan & 4 & $\begin{array}{l}\text {-membuat reading log,log } \\
\text { kosa kata baru, jurnal } \\
\text { masalah. } \\
\text {-projek disampaikan di kelas }\end{array}$ \\
\hline Presentasi & 2 & \\
\hline Kuis & 1 & \\
\hline
\end{tabular}

Nilai akhir dihitung dengan mengalikan nilai $x$ bobot, dijumlah kemudian dibagi 7.

Kategori nilai akhir mengikuti ketentuan yang diatur dalam Pedoman Studi Universitas Pendidikan Ganesha Singaraja

Untuk implementasi nilai karakter dalam pembelajaran, dosen dilengkapi dengan dokumen-dokumen seperti Catatan Anekdot, mengontrol Reading Log yang diisi oleh mahasiswa, Log Kosa Kata Baru, Jurnal Masalah.

Dosen disamping memberikan nilai akhir juga akan membuat penghargaan yang berupa sertifikat untuk menghargai karakter-karakter tertentu yang sudah terbukti membudaya di kalangan mahasiswa yang diajar. 


\section{J. Buku Sumber}

Ni Nyoman Padmadewi (2012) Strategi Pembelajaran Bahasa.

Universitas Pendidikan Ganesha

Wallace, M.J. 1991. Training Foreign Language Teachers: An

effective Approach: New York,CUP

Cooper, M.J (ed). (1994). Classroom Teaching Skills. $5^{\text {th }}$ ed. Lexinton:

D.C. Heath and Company.

\section{K. Rencana Perkuliahan}

\begin{tabular}{|c|c|c|}
\hline $\begin{array}{c}\text { Pertemua } \\
\mathrm{n} \\
\mathrm{Ke}-\end{array}$ & Materi & $\begin{array}{l}\text { Keterangan/ fokus nilai } \\
\text { karakter yang disisipkan }\end{array}$ \\
\hline 1. & $\begin{array}{l}\text { Pendahuluan } \\
\text {-menjelaskan kontrak perkuliahan } \\
\text {-menjelaskan aturan/tata tertib kuliah } \\
\text { - Diskusi tentang phenomena } \\
\text { pembelajaran bahasa jepang yang } \\
\text { ada di sekolah saat ini }\end{array}$ & $\begin{array}{l}\text { Jujur, kerja keras, } \\
\text { bertanggung jawab, disiplin. }\end{array}$ \\
\hline $2-3$ & Pendekatan, metode dan teknik & Cooperative, tenggang rasa \\
\hline 4. & Metode Translasi Gramatika (GTM) & Rajin, kerja keras, \\
\hline 5. & Direct Method & $\begin{array}{l}\text { Jujur, mau menerima kritik } \\
\text { dan saran orang lain }\end{array}$ \\
\hline 6. & Metode Audiolingual & $\begin{array}{l}\text { Dispilin, kerja keras, } \\
\text { cooperative }\end{array}$ \\
\hline 7. & Total Physical Response (TPR) & Tanggung jawab \\
\hline 8. & $\begin{array}{l}\text { Community Language Learning } \\
\text { (CLL) }\end{array}$ & Tekun \\
\hline $9-10$ & $\begin{array}{l}\text { Communicative Language Teaching } \\
(\mathrm{CLT})\end{array}$ & Tekun, disiplin \\
\hline $11-13$ & Pembelajaran kooperatif. & $\begin{array}{l}\text { Cooperative, tanggung } \\
\text { jawab }\end{array}$ \\
\hline 14. & $\begin{array}{l}\text { Strategi pembelajaran menggunakan } \\
\text { lagu }\end{array}$ & Tekun dan kerja keras \\
\hline 15. & $\begin{array}{l}\text { Strategi Pembelajaran menggunakan } \\
\text { permainan }\end{array}$ & $\begin{array}{l}\text { Kerjasama dan bertanggung } \\
\text { jawab }\end{array}$ \\
\hline 16. & Reviu & $\begin{array}{l}\text { Disiplin Cooperative, Jujur, } \\
\text { kerja keras bertanggung } \\
\text { jawab }\end{array}$ \\
\hline
\end{tabular}

Dibuat oleh: Ni Nyoman Padmadewi 


\section{Dilarang memperbanyak sebagian atau seluruh isi dokumen tanpa ijin tertulis dari Jurusan Pendidikan Bahasa Jepang Fakultas Bahasa dan Seni, Undiksha}

Diperiksa oleh:

Seperti dapat dilihat dalam silabus di atas, dapat dinyatakan bahwa silabus yang ditetapkan di Fakultas Bahasa dan Seni dilengkapi dengan informasi agar kendali mutu bisa dilaksanakan. Silabus tersebut di atas dilengkapi dengan Satuan Acara Perkuliahan yang menyajikan persiapan pembelajaran di tiap-tiap pertemuan.

\section{Satuan Acara Perkuliahan (SAP) Mata Kuliah Strategi Pembelajaran Bahasa}

Produk kedua yang dihasilkan dari penelitian ini adalah SAP (Satuan Acara Perkuliahan) yang merupakan penjabaran dari silabus perkuliahan. SAP dibuat sebagai perencanaan pembelajaran di setiap pertemuan. Berdasarkan informasi yang dibuat dalam silabus perkuliahan, jumlah keseluruhan pertemuan dalam satu semester dengan bobot dua (2) satuan kredit semester (sks) adalah 16 kali pertemuan dengan jumlah 15 kali sesi tatap muka ditambah dengan sekali midterm tes dan projek sebagai bentuk tagihan di akhir semester.

Rancangan kegiatan untuk tiaptiap SAP bisa dipaparkan sebagai berikut (SAP secara utuh dan lengkap dibuat/dicetak dalam dokumen tersendiri).

a. Halaman Judul

Berisi tentang judul SAP dan dipakai sebagai sampul dokumen. Identitas mata kuliah di sini agar pengguna mudah mengidentifikasi SAP mata kuliah tersebut. b. Halaman pengantar

Bagian ini berisi tentang informasi umum tentang SAP yang juga berfungsi sebagai pengantar SAP. Bagian ini juga menginformasikan tentang panduan menggunakan SAP agar penggunaannya efektif. Di dalam pengantar juga disebutkan bahwa dosen memiliki fleksibilitas untuk mengubah SAP jika dipandang perlu.

c. Bagian inti SAP

Bagian inti SAP mulai ditulis di bagian ini. SAP dibuat dalam bentuk tabel agar memudahkan untuk melihat korelasi antara satu bagian dengan yang lain. Format bisa ditulis dengan cara lain asal semua komponen SAP bisa dicantumkan yang terdiri dari : idenditas mata kuliah, nomor sesi, Standar Kompetensi, Kompetensi Dasar, Indikator, Materi, Metode/Teknik, Asesmen, alokasi waktu, Nilai karakter, ICT dan sumber materi.

\section{Instrumen Asesmen}

Produk ketiga yang dibuat adalah mengembangkan instrumen asesmen. Ada dua asesmen yang dibuat untuk mata kuliah ini yaitu asesmen untuk mid-term test dan juga asesmen untuk tentamen. Di samping itu sesuai dengan kebijakan lembaga tentang pendidikan karakter, dalam penelitian ini juga perlu dikembangkan instrumen untuk mencatat perkembangan karakter mahasiswa selama mengikuti

Jurnal Pendidikan Indonesia |548 
perkuliahan di Jurusan Pendidikan Bahasa Jepang.

Ada dua asesmen yang dibuat untuk mata kuliah ini yaitu asesmen untuk ujian tengah semester dan juga asesmen untuk tentamen. Di samping itu sesuai dengan kebijakan lembaga tentang pendidikan karakter, dalam penelitian ini juga perlu dikembangkan instrumen untuk mencatat perkembangan karakter mahasiswa selama mengikuti perkuliahan di Jurusan Pendidikan Bahasa Jepang. Di samping menggunakan ketiga jenis instrumen asesmen tersebut, dosen juga memiliki flesibilitas untuk mengembangkan instrumen untuk menilai perkembangan kemampuan mahasiswa yang berlangsung selama proses pembelajaran. Jenis tes ini bisa berupa quis atau bisa juga tes-tes kecil yang bisa dipakai oleh dosen sebagai cara untuk mengukur tingkat pemahaman mahasiswa tentang topik yang diajarkan pada saat itu.

Berikut ini adalah contoh tes yang dipakai untuk tes tengah semester.

$$
\begin{gathered}
\text { STRATEGI PEMBELAJARAN BAHASA } \\
\text { JURUSAN PENDIDIKAN BAHASA JEPANG }
\end{gathered}
$$

\section{PERTANYAAN}

PEMAHAMAN TERHADAP KONDISI DAN FENOMENA PEMBELAJARAN BAHASA JEPANG DI SEKOLAH SAAT INI

1. Jelaskan bagaimana proses pembelajaran bahasa Jepang saat ini di sekolah dilihat dari implementasi kurikulum Bahasa Jepang.

2. Jelaskan masalah yang sering muncul dalam hal pembuatan perencanaan pembelajaran (RPP)!

3. Pendekatan apa yang dipakai oleh guru dalam pembelajaran Bahasa Jepang di SMA/SMK?

4. Menurut pendapat Anda apa kelemahan dan keunggulan dari pembelajaran Bahasa Jepang pada umumnya yang terjadi di sekolah saat ini? Berikan jawaban pada tataran metode dan strategi!

5. Bagaimana prosedur pembelajaran yang khas yang dilakukan oleh guru Bahasa Jepang pada umumnya di sekolah?

6. Menurut pendapat Anda apa yang sebaiknya dilakukan agar guru di sekolah bisa meningkatkan keterampilannya mengajar Bahasa jepang di sekolah?

\section{PENDEKATAN, METODE, DAN TEKNIK}

1. Jelaskan konsep pendekatan? Jenis teori bahasa apa yang telah ada yang dipakai sebagai landasan pembelajaran Bahasa Jepang selama ini?

2. Berikan contoh teori bahasa yang dipakai sebagai landasan dalam pembelajaran bahasa Jepang.

3. Teori pembelajaran bahasa apa yang banyak dipakai di sekolah oleh guru bahasa Jepang di sekolah? 
4. Jelaskan korelasi antara pendekatan, , metode dan teknik !

5. Apa perbedaan antara konsep metode dari Antony dan design dari Richards dan Rodegrs!

GRAMMAR-TRNASLATION METHOD

1. Apa prinsip - prinsip dari Grammar Translation Method? Menurut pendapat anda apakah metode ini cocok dan tepat untuk dipakai di SMA untuk pembelajaran Bahasa Jepang?

2. Jelaskan bagaimana prosedur pengajaran Grammar translation Method?

3. Apa karakteristik utama dari GTM? Seberapa cocok metode ini sesuai dengan situasi yang ada sekarang di sekolah?

4. Apa alasan kenapa GTM dianggap gagal dan tidak banyak dipakai dalam pengajaran bahasa asing di Indonesia sekarang?

5. Apa kelemahan dan keunggulan GTM?

6. Usaha apa yang bisa Anda rekomendasikan agar metode ini menjadi inovatif dan bisa dipakai dalam konteks pembelajaran bahasa Jepang di Bali?

DIRECT METHOD

1. Jelaskan teori bahasa dan teori pembelajaran bahasa yang digunakan sebagai dasar dalam implementasi Direct Method di sekolah?

2. Apa design Direct method? Jelaskan dari sisi tujuan, silabus, peranan materi pembelajaran, peranan guru dan peranan siswa di kelas.

3. Kalau anda mau mengajar dengan menggunakan Direct Method, apa yang harus Anda pertimbangkan agar metode tersebut bisa dilaksanakan dengan efektif?

4. Apa prinsip-prinsip pelaksanaan Direct Method? Dan apa karakteristiknya?

Ujian akhir semester digunakan untuk menilai pencapaian kompetensi mahasiswa setelah mempelajarai mata kuliah Strategi Pembelajaran Bahasa selama satu semester. Bentuk ujian akhir semester dibuat dalam bentuk projek yang memberikan kesempatan kepada mahasiswa untuk mengekpresikan kompetensinya secara holistik tentang mata kuliah Strategi Pembelajaran Bahasa. Mahasiswa diberikan kesempatan untuk mengungkapkan pemahamannya dan sekaligus penerapannya dalam melaksanakan pembelajaran Bahasa Jepang sebagai bahasa asing.

Berikut ini adalah contoh instrumen yang dipakai untuk tentamen. 


\section{UJIAN AKHIR SEMESTER \\ STRATEGI PEMBELAJARAN BAHASA \\ Kelas IVA-B Jurusan Pendidikan Bahasa Jepang}

Baca petunjuk berikut dengan seksama dan tulis jawaban Anda dengan jelas.

Seandainya saudara mengajar Bahasa Jepang kepada siswa SD, tulislah secara jelas pendekatan, metode dan strategi apa yang saudara pakai untuk mengajar siswa tersebut. Untuk menjawab soal ini saudara diharuskan untuk mengikuti hal-hal berikut.

1. Pilih satu topik bahasan (topiknya bebas) yang akan diajarkan. Topik yang dipilih tidak boleh sama dengan teman lain.

2. Untuk mengajar topik tersebut, jelaskan hal-hal berikut.

2.1 Pendekatan yang saudara pakai (paparkan secara singkat dan jelas teori bahasa dan teori pembelajaran bahasa yang saudara pakai). Jelaskan secara singkat alasannya.

2.2 Metode apa yang akan digunakan untuk mengajar topik tersebut (jelaskan apa metode utama yang dipakai dan metode apa yang dipakai sebagai metode pendukung). Jelaskan secara singkat alasan saudara memilih metode tersebut.

2.3 Jelaskan jenis media yang digunakan.

2.4 Jelaskan langkah-langkah prosedural yang saudara lakukan di kelas dalam mengajarkan topik yang saudara ajarkan (menggunakan permainan dan lagu dianjurkan).

Jawaban Anda harus ditulis dengan ketentuan berikut.

1. Diketik dengan rapi.

2. Dikumpulkan pada hari Kamis tanggal 21 Juni 2012.

3. Karena daftar hadir UAS belum selesai, mahasiswa harus menandatangani di buku agenda dosen pemegang mata kuliah sebagai bukti bahwa saudara mengikuti UAS.

Berdasarkan instrumen di atas dapat dinyatakan bahwa bentuk asesmen yang diberikan kepada mahasiswa bermaksud untuk mengekplorasi kemampuan mahasiswa untuk mengungkapkan ide dan pemikiran secara kritis, dan mereka diberi kesempatan untuk memberikan argumentasi dengan pemikiran kritis dan menunjukkan kompetensinya terhadap konsep yang telah dipelajari sebelumnya.

Di samping produk utama menghasilkan dokumen yang implementasinya bertujuan untuk memperkuat implementasi pendidikan karakter sehingga nilai-nilai karakter yang ingin ditanamkan menjiwai aktivitas mahasiswa dan menjadi kebiasaan mereka. Dokumen yang digunakan bisa berupa Catatan Anekdot, Lembar Kegiatan Mahasiswa dalam bentuk 'Log Kegiatan Membaca' atau 'Log Kosa Kata'. Implementasi dokumen penguatan pendidikan karakter ini perlu diberlakukan dengan menggunakan sistem tertentu dan dinilai/ditindaklanjuti secara serius. Tanpa penggunaan sistem yang tepat dan tanpa adanya penilaian yang memadai, penanaman pendidikan karakter akan sebatas wacana dan tidak dilakukan secara serius. 
Berikut ini adalah contoh format penilaian karakter yang dilakukan terhadap mahasiswa dalam melakukan semua aktivitas di kampus dan di luar kampus yang bisa dilakukan melalui observasi maupun menganalisis perilaku dan tugas/aktivitas yang ditunjukkan mahasiswa.

Kelas :

\begin{tabular}{|c|c|c|c|c|c|c|c|c|c|c|c|c|c|c|c|c|c|c|c|}
\hline \multirow[b]{2}{*}{ NO } & NAM & \multicolumn{18}{|c|}{ NILAI KARAKTER } \\
\hline & $\begin{array}{c}\text { IVAF } \\
\text { ASI } \\
\text { SW } \\
\text { A }\end{array}$ & 1 & 2 & 3 & 4 & 5 & 6 & 7 & 8 & 9 & 10 & 11 & 12 & 13 & 14 & 15 & 16 & 17 & 18 \\
\hline 1 & & & & & & & & & & & & & & & & & & & \\
\hline 2 & & & & & & & & & & & & & & & & & & & \\
\hline 3 & & & & & & & & & & & & & & & & & & & \\
\hline 4 & & & & & & & & & & & & & & & & & & & \\
\hline & Dst & & & & & & & & & & & & & & & & & & \\
\hline
\end{tabular}

Untuk menilai karakter mahasiswa dengan menggunakan rubrik tersebut di atas, dosen melakukan observasi secara berkelanjutan terhadap perilaku dan penampilan serta kegiatan yang dilakukan oleh mahasiswa secara berkelanjutan dan kemudian memberikan penilaian. Penilaian yang diberikan bersifat kualitatif dengan menggunakan rentangan penilaian seperti yang disarankan Wibowo (2012).

1. BT: belum terlihat (apabila peserta didik belum memperlihatkan tandatanda awal perilaku yang dinyatakan dalam indikator).

2. MT: Mulai terlihat (apabila peserta didik sudah mulai memperlihatkan adanya tanda-tanda awal perilaku yang dinyatakan dalam indikator tetapi belum konsisten).

3. MB: Mulai berkembang (apabila peserta didik sudah memperlihatkan berbagai tanda perilaku yang dinyatakan dalam indikator dan mulai konsisten).
4. MK: Membudaya (apabila peserta didik terus menerus memperlihatkan perilaku yang dinyatakan dalam indikator secara konsisten).

Memperhatikan perangkat pembelajaran yang dikembangkan dalam penelitian ini, dapat dinyatakan bahwa semua komponen perangkat pembelajaran saling berhubungan dan mempengaruhi satu sama lain. Menurut Kemp (1994), pengembangan perangkat merupakan suatu lingkaran yang kontinum. Perangkat yang satu memberikan masukan dan kontribusi terhadap keberhasilan terhadap implementasi dari perangkat pembelajaran yang lainnya. Silabus pembelajaran misalnya memberikan dasar panduan untuk mengembangkan SAP dan RPP yang kemudian dinilai dengan menggunakan istrumen asesmen. Hasil penilaian dengan asesmen memberikan masukan terhadap semua domumen yang dipakai sebelumnya.

Jurnal Pendidikan Indonesia |552 
Hasil penilaian yang diperoleh melalui asesmen yang dilakukan oleh dosen baik melalui instrumen tes maupun perangkat pembelajaran yang menguatkan nilai karakter mahasiswa memberikan kesempatan kepada dosen pengajar untuk lebih memahami kemampuan dan karakteristik mahasiswa yang diajarnya. Analisis terhadap perilaku mahasiswa baik yang berupa kemampuan akademis maupun perilaku sosial non akademis bisa dipakai masukan untuk mengetahui keberhasilan pembelajaran yang dilakukan dosen pengampu mata kuliah. Analisis karakteristik mahasiswa merupakan hal yang sangat penting pada awal perencanaan. Analisis ini dilakukan dengan memperhatikan ciri, kemampuan, dan pengalaman baik individu maupun kelompok. Analisis karakteristik mahasiswa meliputi antara lain: kemampuan akademik, usia dan tingkat kedewasaan, motivasi terhadap mata pelajaran, pengalaman, kemampuan psikomotor, kemampuan bekerja sama, keterampilan sosial dan sebagainya (Ibrahim dan Nur, 2000).

Di samping itu, analisis terhadap tugas yang diberikan oleh dosen dan yang dikerjakan oleh mahasiswa juga merupakan hal yang sangat penting dilakukan. Analisis tugas adalah kumpulan prosedur untuk menentukan isi suatu pengajaran (Kemp, et al, 1994: 58). Analisis tugas sejalan dengan analisis tujuan dimana analisis tujuan dilakukan untuk mengetahui dan menentukan model pembelajaran untuk mencapai tujuan.

Analisis tujuan dilakukan untuk mengidentifikasi keterampilanketerampilan subordinat (prasyarat) yang harus dipelajari siswa/mahasiswa dan langkah-langkah prosedur subordinat yang perlu diikuti oleh siswa/mahasiswa untuk mempelajari sebuah proses. Analisis ini akan menghasilkan suatu diagram atau chart yang berisi keterampilan-keterampilan dan hubungan antar keterampilan tersebut (Kardi dan Nur, 2000). Jadi, analisis tugas atau tujuan adalah analisis pelajaran, konsep, pemrosesan informasi yang bertujuan untuk memudahkan pemahaman tentang tugas-tugas belajar dan tujuan pembelajaran yang ingin dicapai.

Nilai karakter yang ingin dikembangkan dibentuk dalam diri mahasiswa disisipkan dalam pembelajaran dan dikuatkan melalui implementasi perangkat pembelajaran sehingga mahasiswa tidak merasakan bahwa mereka belajar tentang pendidikan karakter. Perangkat pembelajaran yang dikembangkan pada prinsipnya merupakan lembar kegiatan mahasiswa yang berupa 'Log Kegiatan Membaca' dan 'Log Kosa kata' yang bertujuan untuk memberikan kesempatan kepada mahasiswa untuk melakukan kegiatan membaca dan menambah kasanah kosa kata Bahasa Jepang yang dipelajari untuk mengembangkan nilai karakter suka membaca, tekun, rajin, rasa ingin tahu, bertanggung jawab.

Di samping itu, dosen bisa juga mencatat setiap perilaku karakter mahasiswa yang dianggap penting dan perlu untuk dianalisis atau ditindak lanjuti dalam dokumen Catatan Anekdot. Catatan Anekdot ini bisa berfungsi sebagai jurnal untuk mencatat perilaku mahasiwa yang bisa dipakai masukan untuk memberikan tindakan berikutnya. 
Untuk menjamin keberhasilan pelaksanaan pendidikan karakter, perlu diadakan sistem penilaian yang dilakukan secara sistematis dan melalui program penilaian dengan menggunakan strategi yang terencana dan penilaian yang berkelanjutan. Karakter yang menyimpang harus diberikan konskuensi sesuai dengan aturan yang disepakati. Catatan anekdot bisa dipakai ketika dosen melihat perilaku yang menonjol yang berkenaan dengan nilai yang dikembangkan. Di samping itu dosen bisa memberikan tugas yang berisikan persoalan yang memberikan kesempatan kepada peserta didik untuk menunjukkan nilai yang dimilikinya.

Berdasarkan hasil pengamatan, catatan anekdot, tugas dan laporan dan sumber lain, dosen dapat memberikan kesimpulan atau pertimbangan tentang pencapaian indikator tentang nilai/karakter yang dikembangkan siswa. Kesimpulan tersebut seperti yang disarankan Wibowo (2012) dapat dinyatakan dalam pernyataan kualitatif seperti yang diungkapkan sebelumnya: "belum terlihat", "mulai tampak", "berkembang", dan " membudaya"

Pernyataan kualitatif tersebut dapat digunakan ketika dosen melakukan asesmen pada setiap kegiatan belajar sehingga guru memperoleh profile peserta didik dalam satu semester tentang nilai terkait. Posisi nilai peserta didik adalah nilai yang ditunjukkan oleh peserta didik pada akhir semester dengan membandingkan kondisi awal dengan pencapaian dalam waktu tertentu. Aspek penilaian ini memberikan implikasi bahwa penilaian terhadap pendidikan karakter bersifat observatif dan harus dilakukan secara kontinu.

\section{PENUTUP}

Sosok kepribadian yang arif dan hikmat, mengedepankan excellent competence, yang memiliki godly characters, sustainable self learning dan spiritual discernment merupakan kunci keberhasilan dalam pemanfaatan, pengembangan dan pelestarian kakayaan geografis, demografis, sosial budaya. Karakteristik sosok manusia ini berpotensi mampu mengembangkan kamampuan emulatif, yaitu humanware, info-ware, organo-ware, teknoware, untuk menhasilkan produk teknologi yang berkualitas tinggi, lowcost, low risk, highly competitive di era global (Mukhadis, 2013) yang sangat dibutuhkan di negara Indonesia sebagai agen pembaharu dan pencetak tunas bangsa yang berkualitas.

Guru/dosen sebagai agen pembaharuan dan sebagai pendidik profesional harus dibina agar memiliki wawasan untuk mendukung dan mengembangkan nilai-nilai tersebut di atas, sehingga dalam melaksanakan tugas profesionalnya dapat menanamkan hal tersebut pada diri peserta didik. Guru/dosen sebagai insan profesional harus ahli dalam bidangnya; harus tampil sopan, anggun, simpati dan menjadi teladan; dan mendidik peserta didik dengan hati yang tulus dan dapat berperan menjadi guru dihati murid; serta semua komponen itu menjadi jiwa (spirit) guru yang profesional. 


\section{DAFTAR PUSTAKA}

Dick, W. \& Carey, L. 1990. The Systematic Design of Instruction. Second Edition. Illinois: Scott, Foresman and Company

Ibrahim, M., dan Nur, M. 2000. Pengajaran Berdasarkan Masalah. Surabaya: Univeresity Press.

Kardi, S. dan Nur, M. 2000. Pengajaran Langsung. Surabaya: University Press

Kemp, J.E., Morisson, g.R., and Ross, S.M. 1994. Designing Effective Instruction. New York: Macmillan College Publishing Company.

Killen, Roy. 1998. Effective Teaching Strategies. Katoomba NSW: Social Science Press

Krashen, S. (1995). Second Language Acquisition and Seconda Language Learning. Oxford: Pergamon Press.

Mukhadis, Amat. 2013. Sosok Manusia Indonesia Unggul dan Berkarakter dalam Bidang

Teknologi sebagai Tuntutan Hidup di Era Globalisasi. Jurnal Pendidikan Karakter, Thn III, No.2.

Padmadewi, Ni Nyoman.2012. Pengembangan Bahan Ajar Mata Kuliah Strategi Pembelajaran
Bahasa untuk Jurusan Pendidikan Bahasa Jepang Universitas Pendidikan Ganesha Singaraja. (Laporan Hasil Penelitian yang tidak dipublikasikan)

Panduan Pendidikan Karakter di sekolah Menengah Pertama Kementrian Pendidikan Nasional Direktorat jenderal Pendidikan Dasar dan Menengah Direktorat Pembinaan Sekolah Menengah Pertama 2010).

Pedoman Pelaksanaan Pendidikan Karakter Kementrian Pendidikan Nasional Badan penelitian dan Pengembangan Pusat Kurikulum dan Perbukuan, 2011

Pendidikan Karakter di Peguruan Tinggi, Kementrian Pendidikan Nasional Direktorat Pendidikan Tinggi Tahun 2011

Sri Adnyani, Luh; I Nyoman Pasek Hadisaputra, Wayan Sadyana. 2011. Studi Penelusuran Alumni Fakultas Bahasa dan Seni Universitas Pendidikan Ganesha Singaraja (laporan penelitian tidak dipublikasikan).

Wibowo, Agus. 2012. Pendidikan Karakter. Strategi Membangun Karakter Bangsa Berperadaban. Yogjakarta: Pustaka Belajar. 